\title{
DiPaolo, M. (2021) Fake Italian: An 83\% True Autobiography with Pseudonyms and Some Tall Tales. Bordighera Press.
}

\author{
Review by Michelle M. Tokarczyk
}

Fake Italian is a quintessentially American, quintessentially twentieth-century bildungsroman. Damien Cavalieri, its protagonist, is haunted by the feeling that he is a 'fake Italian.' He had no Italian-American friends in his elementary school, despite Staten Island's being a New York City borough heavily populated by Italian-Americans. As Damien reaches adulthood he comes to terms with his ethnic background, as well as with other crucial identity questions, such as masculinity and intellectuality.

Fake Italian spans Damien's youth from the ages of eleven to twenty-two. The book begins with his first day of middle school and his fateful decision to leave the gifted program because its students could not study Italian, and Damien wants to learn the language of his ancestors. But his move places him with less intellectual students for whom reading is uncool, and Damien unwittingly reinforces their perceptions by wearing a suit on the first day of classes. His classmates, many of whom are ItalianAmerican, read his bookishness as a sign that he is Jewish, which intensifies Damien's feelings that he is not an authentic Italian. He endures mockery from girls and boys alike; worse, boys beat him and pelt him with stones. (His mother rescues him.) Damien endures by acting on the advice of his martial arts instructor Master Park (a woman) to use humor as a defense. The pages of Fake Italian are filled with self- deprecating, ironic humor.

As a member of Generation X, Damien belongs to the first cohort of latchkey children who spent hours a day with television shows and comic books. Damien makes countless references to iconic movies and television shows, such as Jaws and Colombo, as well as to Marvel comic characters-especially Wonder Woman. For Damien, popular genres such as science fiction, horror, and fantasy represent an escape from his insular environment, but also a possibility that alternative lives are possible.

Fake Italian is not about working-class identity. Damien bemoans the cookie-cutter appearance of Staten Island houses constructed for the working- and lower-middle classes. Usually, he describes himself and his family as middle class. However, the marriage of Damien's parents' is a fascinating depiction of gender and class dynamics. Working-class studies' scholars might describe this marriage as a cross-class one. His mother was making steady progress toward her doctorate in English; but she was married, had two children, and a spouse whose earnings were scant. She struggled to balance motherhood, teaching, and graduate studies. When her request for a leave of absence from the NYU graduate program was callously refused, she withdrew from the program, forfeiting the possibility of a tenure-track appointment teaching literature as well as composition. Luckily, she got a position teaching composition and eventually earned tenure. Damien, however, compares his mother's work of grading hundreds of remedial composition papers to a factory job. Significantly, she appears to be a changed person when she retires. In contrast, Damien's father, traumatized by childhood experiences, works at a 
series of low-level positions, making his wife the breadwinner. He clings to markers of masculinity, remaining unwilling to help with household chores and expecting his wife to put dinner on the table. His sons follow his example, if with some guilt. The accumulated force of institutional sexism in both marriage and academia is too powerful to be overcome.

During his high-school years Damien, who identifies with his mother far more than with his father, struggles to form his own vision of manhood. He's chagrined by his father's flirtatious ways and his grandfather's reputation as a sex maniac. Friends press Damien to have a sexual experience, but he is more eager for a love relationship. Yet the girls to whom he is attracted are unavailable. Arwen, a Jewish soon-to-be heiress whose family will disown her if she marries a gentile, is his love for years. She reciprocates his feelings, but cannot act on them, and eventually marries someone else. Despite his disappointments in love, Damien remains unwilling to 'hook up' for sex. He is too sensitive and respectful of women to behave in this way.

In many ways, Damien is ill-fitted for a capitalist patriarchal society. During his college years this mismatch crystalizes in an argument with Sergio, a business major, who sees his undergraduate degree as a ticket to financial success. Damien, in contrast, sees his college years as an opportunity to learn about himself and acquire knowledge. In a nation where action is prioritized over thought, intellectuals such as Damien are marginalized. Similarly, although a Catholic and a Republican, Damien recoils from anti-choice Catholics who are unable to empathize with women. His need to solidify and live his values results from a tragedy: his best friend, Mitchell, was killed in a car accident. He wants to honor his friend's life by being as compassionate and as astute as Mitchell was.

To immerse himself in his heritage, Damien travels to Italy. Here he has a pivotal conversation about Italian identity. In response to Damien's bemoaning his 'fake' status, a stranger tells him that Italy was never meant to be a nation of one people. There are many types of Italians, and those who emigrated are among the best of them. More provocatively, the stranger states that the imposter syndrome is a technique of class warfare designed to impede solidarity. Ultimately, the stranger leaves Damien with the clichéd but very useful advice that he should be himself.

Overall, Fake Italian is an engaging and very well-written reflection on coming of age as an ItalianAmerican male intellectual. Yet a book of 543 pages makes considerable demands on readers' time. The story of Damien's infatuation with Arwen might be condensed. Similarly, the numerous pop culture references - many of which will be unrecognizable within a few years - could be pruned. Fake Italian, however, is a valuable and enjoyable text for those interested in ethnicity, popular culture, and contemporary forms of the bildungsroman.

\section{Reviewer Bio}

Michelle Tokarczyk is professor emerita of English and an emerita affiliate of Women's, Gender, and Sexuality Studies at Goucher College. In addition to edited volumes on working-class literature and critical studies of Maxine Hong Kingston, Sandra Cisneros, Dorothy Allison, and E.L. Doctorow, she has published two volumes of poetry, Bronx Migrations and The House I'm Running From. 